\title{
KURIKULUM NASIONAL YANG BERBASIS KOMPETENSI PERGURUAN TINGGI DENGAN MENGACU PADA KERANGKA KUALIFIKASI NASIONAL INDONESIA (KKNI) UNTUK MENGHASILKAN KUALITAS MANUSIA YANG KOMPETEN DAN BERDAYA SAING
}

Oleh:

Christin Septina Basani

\begin{abstract}
Human resource needs, especially in the economy is the main source to sustain a nation. Human resources are created in a competent workforce and quality into its own competitiveness. Indonesian nation will enter the ASEAN Economic Community (AEC) will need to create a competent human resources. College as one of the graduates are ready to use in the workplace. One key factor is the quality of college graduates through the curriculum. Competency-based national curriculum with reference to national qualifications frameworks Indonesia will generate human resources in Indonesia are competent and competitive.
\end{abstract}

Keywords: human resources, college, graduate, competency-based curriculum, KKNI

\section{PENDAHULUAN}

Perguruan Tinggi adalah salah satu jenjang pendidikan bagi setiap orang, dimana tahap pemahaman, pengembangan dan implementasi terhadap bidang keilmuan jauh lebih tinggi tingkatannya dibandingkan jenjang pendidikan tingkat Sekolah Dasar, Sekolah Menengah Pertama maupun Sekolah Menengah Umum. Karena harapannya Perguruan Tinggi mencetak lulusan yang siap bekerja dalam kompetensi dan bidang keahliannya masing-masing. Kebutuhan yang tinggi pada dunia kerja untuk setiap lulusan perguruan tinggi membuat perguruan tinggi mencoba menyiapkan materi pada setiap mata kuliahnya setidaknya menjawab kebutuhan para pengguna tenaga lulusan perguruan Tinggi. Penyusunan materi

\footnotetext{
${ }^{1}$ E. Mulyasa, Implementasi Kurikulum 2004 Panduan Pembelajaran KBK, Remaja Rosda Karya; 2005, hlm.23.
}

tertuang dalam kurikulum yang disusun oleh masing-masing perguruan tinggi. Penyusunan kurikulum harus melihat lulusan perguruan tinggi nantinya siap menjadi lulusan yang kompeten dalam bidangnya.

\section{PEMBAHASAN}

Kurikulum yang digunakan dalam perguruan tinggi saat ini banyak mengacu pada penyusunan kurikulum yang berbasis kompetensi (atau sering kita sebut KBK). Kompetensi merupakan perpaduan dari pengetahuan, keterampilan, nilai dan sikap yang direfleksikan dalam kebiasaan berfikir dan bertindak. Menurut Crunkilton dalam Mulyasa, mengemukakan bahwa kompetensi ialah sebagai penguasaan terhadap suatu tugas, keterampilan, sikap dan apresiasi yang diperlukan untuk menunjang keberhasilan. ${ }^{1}$ 
Hal tersebut menunjukkan bahwa kompetensi mencakup tugas, keterampilan, sikap dan apresiasi yang harus dimiliki oleh peserta didik untuk dapat melaksanakan tugas-tugas pembelajaran sesuai dengan jenis pekerjaan tertentu. Dengan demikian terdapat hubungan (link) antara tugas-tugas yang dipelajari peserta didik di sekolah dengan kemampuan yang diperlukan oleh kerja. $^{2}$

Kompetensi yang harus dikuasai peserta didik dinyatakan sedemikian rupa agar dapat dinilai. Sebagai wujud hasil belajar peserta didik yang mengacu pada kreativitas belajarnya. Peserta didik perlu mengetahui tujuan belajar, dan tingkat-tingkat penguasaan yang akan digunakan sebagai kriteria pencapaian secara eksplisit, dikembangkan berdasarkan tujuan-tujuan yang telah ditetapkan memiliki kontribusi terhadap kompetensi yang sedang dipelajari.

Menurut Gordon dalam Mulyasa, menjelaskan beberapa aspek atau ranah yang terkandung dalam konsep kompetensi sebagai berikut: ${ }^{3}$

1. Pengetahuan (knowledge) yaitu kesadaran dalam bidang kognitif, misalnya seorang guru mengetahui cara melakukan identifikasi kebutuhan belajar, dan bagaimana melakukan pembelajaran terhadap peserta didik sesuai dengan kebutuhannya;

2. Pemahaman (understanding) yaitu kedalaman kognitif, dan afektif yang dimiliki oleh individu;

3. Kemampuan (skill) adalah sesuatu yang dimiliki oleh individu untuk melakukan tugas atau pekerjaan yang dibebankan kepadanya;
4. Sikap (attitude) yaitu (senang atau tidak senang, suka tidak suka) atau reaksi terhadap suatu rangsangan terhadap yang datang dari luar;

5. Minat (interest) adalah kecenderungan seseorang untuk melakukan sesuatu atau perbuatan.

Kompetensi yang diawali dengan pengetahuan pada suatu bidang keilmuan tertentu, disertai dengan pemahaman memunculkan suatu kemampuan. Adanya pengaruh dari sikap dan minat membuat kompetensi yang sudah didahului dengan pengetahuan, pemahaman serta kemampuan, membuat kompetensi semakin terarah. Berdasarkan gambaran kompetensi di atas, maka kurikulum berbasis kompetensi adalah suatu konsep kurikulum yang menekankan pada pengembangan kemampuan kompetensi tugas-tugas dengan standar performasi tertentu sehingga hasilnya dapat dirasakan oleh peserta didik berupa penguasaan terhadap seperangkat kompetensi tersebut. Dengan demikian penerapan kurikulum dapat menumbuhkan tanggung jawab, dan partisipasi peserta didik untuk belajar menilai dan mempengaruhi kebijakan umum, serta memberanikan diri berperan dalam berbagai kegiatan di sekolah maupun masyarakat.

Kurikulum Berbasis Kompetensi (KBK) diarahkan untuk mengembangkan pengetahuan, pemahaman, kemampuan, nilai, sikap, dan minat peserta didik agar dapat melakukan sesuatu dalam bentuk kemahiran, ketepatan, dan keberhasilan dengan penuh tanggung jawab. KBK memfokuskan pemerolehan kompetensikompetensi tertentu oleh peserta didik. Oleh karena itu kurikulum ini mencakup sejumlah

${ }^{3} \mathrm{Op}, \mathrm{Cit}, \mathrm{hlm} .77-78$.

\footnotetext{
2 www.dikti.go.id; Membumikan Pendidikan; Juli 2014, diakses pada tanggal 30 Oktober 2015
} 
kompetensi, dan seperangkat tujuan pembelajaran yang dinyatakan sedemikian rupa. Sehingga pencapaiannya dapat diamati dalam bentuk perilaku atau keterampilan peserta didik sebagai sesuatu kriteria keberhasilan. Kurikulum berbasis kompetensi (KBK) juga menuntut guru yang berkualitas dan profesional untuk melakukan kerjasama dalam rangkaian meningkatkan kualitas pendidikan. Dalam hubungannya dengan pembelajaran memenuhi spesifikasi tertentu dalam proses belajar.

Kay dalam Mulyasa, mengemukakan bahwa "pendidikan berbasis kompetensi selalu dilandasi oleh rasionalitas yang dilakukan dengan penuh kesadaran "mengapa" dan "bagaimana" jadi "perbuatan tersebut dilakukan". ${ }^{4}$ Bila dikorelasikan dengan perguruan tinggi, KBK menuntut dosen yang ditunjang dengan kurikulum untuk mengahasilkan lulusan mengerti bidang keilmuannya dan pengaplikasiannya dimasyarakat seperti apa terhadap persoalan yang dihadapi atau terhadap bidang pekerjaannya.

Ada pendapat bahwa kurikulum berbasis kompetensi berorientasi pada kreativitas individu untuk melakukan sesuatu dalam bentuk kemahiran dan efek (dampak) yang diharapkan yang muncul dari peserta didik melalui serangkaian pengalaman belajar yang bermakna, dan keberagaman yang dapat dimanifestasikan sesuai dengan kebutuhannya. Rumusan kompeten dalam kurikulum berbasis kompetensi ini merupakan pernyataan apa yang diharapkan dapat diketahui, disikapi, atau dilakukan siswa dalam setiap tingkatan kelas dan Madrasah, sekaligus menggambarkan kemajuan siswa yang dicapai secara bertahap dan berkelanjutan untuk menjadi kompeten. KBK merupakan suatu konsep kurikulum yang menekankan pada pengembangan kemampuan melakukan (kompetensi) tugastugas oleh peserta didik berupa penguasaan terhadap seperangkat pengetahuan, kemampuan, sikap dan minat peserta didik agar dapat melakukan sesuatu dalam bentuk kemahiran dengan penuh tanggung jawab.

Bila dikorelasikan dengan perguruan tinggi kurikulum yang disusun merupakan kurikulum yang harus bisa diketahui, dipahami, disikapi dan dilakukan oleh mahasiswa serta ada kemajuan secara bertahap terhadap keilmuan yang diperolehnya. Dalam proses pembelajaran melalui tugas-tugas yang diberikan akan terlihat peserta didik mempunyai pemahaman atau tidak dengan ilmu yang sudah diberikan, serta hasil akhirnya berupa lulusan yang mempunyai sikap, minat serta penguasaan terhadap pengetahuan yang didapat berupa kemahiran terhadap bidang keilmuannya.

Dalam KBK kemampuan yang dimiliki peserta didik untuk berkreasi dan berimajinasi jika diberikan kesempatan dan peran aktif dosen terhadap mahasiswa yang secara tidak langsung akan memberikan dampak terhadap penguasaan apa yang telah diajarkan dosen. Hal ini akan terlihat dalam proses belajar mengajar ketika dosen melontarkan suatu masalah, mahasiswa mampu memberikan solusi atau cara mengatasinya. Pemahaman dan imajinasi serta inisiatif akan terlihat oleh mahasiswa, sejauh mana pemahamannya terhadap materi yang diberikan. Kurikulum berbasis kompetensi menuntut tenaga pengajar yang berkualitas dan profesional untuk melakukan kerjasama dalam rangka meningkatkan kualitas pendidikan. Meskipun demikian konsep KBK ini tentu saja tidak dapat digunakan sebagai resep untuk memecahkan

\footnotetext{
${ }^{4}$ Ibid.
} 
semua masalah pendidikan, namun dapat memberi sumbangan yang cukup signifikan, terhadap perbaikan pendidikan. ${ }^{5}$

\section{Karakteristik Kurikulum Berbasis kompetensi}

Karakteristik berbasis kompetensi antara lain mencakup seleksi kompetensi yang sesuai, spesifikasi indikator-indikator evaluasi untuk menentukan kesuksesan pencapaian kompetensi dan pengembangan sistem pembelajaran. Di samping itu KBK memiliki sejumlah kompetensi yang harus dikuasai peserta didik. Penilaian dilakukan berdasarkan standar khusus sebagai hasil demostrasi kompetensi yang ditunjukkan oleh peserta didik, pembelajaran lebih menekankan pada kegiatan individual personal untuk menguasai kompetensi yang dipersyaratkan, peserta didik dapat dinilai kompetensinya.

Departemen Pendidikan Nasional mengemukakan bahwa kurikulum berbasis kompetensi memiliki karakteristik sebagai berikut:

1. Menekankan pada ketercapaian kompetensi peserta didik baik secara individual maupun klasikal;

2. Berorientasi pada hasil belajar (learning out comes) dan keberagaman;

3. Penyampaian dalam pembelajaran menggunakan pendekatan dan metode yang bervariasi;

4. Sumber belajar bukan guru, tetapi juga sumber belajar lainnya yang memenuhi unsur edukatif;

5. Penilaian menekankan pada proses dan hasil belajar dalam upaya penguasaan atau pencapaian suatu kompetensi.
Dari beberapa rumusan tentang karakteristik kurikulum berbasis kompetensi di atas jelaslah bahwa pada pencapaian kompetensi itu dilihat dari cara penyampaian materi oleh tenaga pengajar dan metode yang digunakan dalam pembelajaran lebih lanjut dikatakan bahwa penilaian Kurikulum Berbasis Kompetensi adalah dilihat dalam kompetensi tenaga pengajar dalam persiapan mengajar, artinya ada upaya tenaga pengajar untuk menguasai materi yang memenuhi syarat atau unsur edukatif. Karena yang diinginkan dalam kompetensi ini adalah menekankan pada kualitas siswa, dan hasil belajar yang dicapai.

Ada enam hal karakteristik kurikulum berbasis kompetensi. Enam hal tersebut dijelaskan sebagai berikut:

a. Sistem Belajar Dengan Modul

Kurikulum berbasis kompetensi menggunakan modul sebagai sistem pembelajaran. Dalam hal ini modul merupakan paket belajar mandiri yang meliputi serangkaian pengalaman belajar mandiri yang meliputi serangkaian pengalaman belajar yang direncanakan dan dirancang secara sistematis untuk membantu peserta didik, untuk mencapai tujuan belajar.

Modul adalah "suatu proses pembelajaran mengenai satuan bahasan tertentu yang disusun secara sistematis, operasional, dan terarah untuk digunakan oleh peserta didik, disertai dengan pedoman penggunaannya untuk para guru". Pembelajaran dengan sistem modul memiliki karakteristik sebagai berikut:

1. Setiap modul harus memberikan informasi dan memberikan petunjuk pelaksanaan yang jelas tentang apa yang harus dilakukan seorang peserta 
didik, bagaimana melakukannya dan sumber belajar apa yang digunakan;

2. Modul merupakan pembelajaran individual, sehingga mengupayakan untuk melibatkan sebanyak mungkin karakteristik peserta didik;

3. Pengalaman belajar dalam modul disediakan untuk membantu peserta didik untuk mencapai tujuan pembelajaran;

4. Materi pembelajaran disajikan secara logis dan sistematis sehingga peserta didik dapat mengetahui, kapan mengakhiri suatu modul;

5. Setiap modul memiliki mekanisme untuk mengukur pencapaian tujuan belajar peserta didik.

Dari beberapa penjelasan di atas bahwa proses pembelajaran dengan menggunakan sistem modul akan mempercepat proses belajar mengajar sekaligus mengarahkan peserta didik pada pencapaian pembelajaran. Sistem modul ini juga memiliki mekanisme yang jelas dan disajikan secara logis dan sistematis, sehingga peserta didik dapat mengetahui apa yang dia pelajari, karena prosesnya dilaksanakan secara individual.

\section{b. Menggunakan Keseluruhan Sumber Belajar \\ Dalam KBK tenaga pengajar tidak} lagi menjadi peran utama dalam proses pembelajaran karena pembelajaran dapat menggunakan aneka ragam sumber belajar seperti: manusia, bahan belajar (buku) dan lingkungan.

\section{c. Pengalaman Lapangan}

KBK lebih menekankan pada pengalaman lapangan untuk mengakrabkan hubungan antara tenaga pengajar dengan peserta didik yang yang akan meningkatkan pengetahuan, pemahaman yang lebih leluasa bagi tenaga pengajar dan peserta didik.

\section{d. Strategi Belajar Individual Personal}

Belajar individual adalah belajar berdasarkan tempo belajar peserta didik sedangkan belajar personal adalah interaksi edukatif dalam rangka mengembangkan strategi individual personal mengembangkan program KBK melibatkan ahli terutama ahli psikologi.

\section{e. Kemudahan Belajar}

Kemudahan dalam KBK diberikan melalui kombinasi antara pembelajaran individual personal dengan pengalaman dan pembelajaran secara tim.

\section{f. Belajar Tuntas \\ Belajar tuntas merupakan strategi pembelajaran yang dapat dilaksanakan dalam kelas dengan asumsi, bahwa di dalam kondisi yang tepat semua peserta dengan baik dan memperoleh hasil belajar maksimal.}

Dari uraian di atas, sistem pembelajaran dalam KBK jika dilihat karakteristik khusus bahwa sistem pembelajaran dalam KBK sangatlah praktis untuk pengembangan peserta didik, dalam arti dengan sistem ini sifatnya universal yang telah mencakup secara keseluruhan kegiatan pembelajaran yang menjadi kebutuhan pokok peserta didik. Secara jelas, peranan tenaga pengajar dalam sistem penyajian modul hanya merupakan sumber tambahan dan pembimbing yang membimbing peserta didik, namun tidak menutup kemungkinan peserta didik membutuhkan arahan dan pembinaan tenaga pengajar secara intensif, dalam rangka mencapai tujuan pendidikan profesional. 


\section{Prinsip Kurikulum Berbasis Kompetensi}

Sesuai dengan prinsip diversifikasi dan desentralisasi pendidikan maka pengembangan kurikulum ini digunakan prinsip dasar "kesatuan dalam kebijakan dan keberagaman dalam pelaksanaan" prinsip kesatuan dalam kebijakan yaitu dalam mencapai tujuan pendidikan perlu ditetapkan standar kompetensi yang harus dicapai secara nasional pada setiap jenjang pendidikan. Sedangkan prinsip keberagaman dalam pelaksanaan yaitu dalam menyelenggarakan pendidikan yang meliputi perencanaan dan pelaksanaan kegiatan pembelajaran penilaian dan pengelolaannya mengakomodasikan perbedaan yang berkaitan dengan kesiapan dan potensi akademik, minat lingkungan, budaya, dan sumber daya sekolah sesuai dengan karakteristik satuan pendidikan masing-masing.

"Pengembangan kurikulum merupakan suatu proses yang kompleks, dan melibatkan berbagai faktor yang saling terkait".

Pengembangan Kurikulum Berbasis Kompetensi menfokuskan pada kompetensi tertentu berupa pedoman pengetahuan, keterampilan, dan sikap yang didemostrasikan peserta didik sebagai wujud pemahaman terhadap konsep yang dipelajarinya. Penerapan kurikulum berbasis kompetensi memungkinkan para tenaga pengajar menilai hasil belajar yang mencerminkan penguasaan dan pemahaman terhadap apa yang dipelajarinya. Secara rinci pengembangan KBK mempertimbangkan hal-hal berikut:

1. Keimanan, nilai-nilai dan budi pekerti luhur yang perlu digali, dipahami dan diamalkan peserta didik;

\footnotetext{
${ }^{6}$ Sudjatmiko, et.all; Kurikulum Berbasis Kompetensi Dalam Menunjang Kecakapan Hidup Siswa; Jakarta: Depdiknas 2003,
}

2. Penguatan integritas nasional yang dicapai melalui pendidikan;

3. Keseimbangan berbagai bentuk pengalaman belajar siswa yang meliputi etika, logika, estetika dan kinestetika;

4. Penyediaan tempat yang memberdayakan semua siswa untuk memperoleh pengetahuan, keterampilan dan sikap sangat diutamakan seluruh peserta didik dari berbagai kelompok;

5. Kemampuan berfikir dan belajar dengan mengakses, memilih, dan menilai pengetahuan untuk mengatasi situasi yang cepat berubah dan penuh ketidakpastian merupakan kompetensi penting dalam menghadapi perkembangan ilmu pengetahuan dan teknologi;

6. Berpusat pada anak dengan penilaian yang berkelanjutan dan komperehensif. ${ }^{6}$

Prinsip dasar kegiatan belajar mengajar menurut Departemen Pendidkan Nasional yang dikembangkan dalam KBK adalah mengembangkan kemampuan berfikir logis, kritis, kreatif, bersikap dan bertanggung jawab pada kebiasaan dan perilaku seharihari melalui pembelajaran secara aktif yaitu: berpusat pada siswa; mengembangkan keingintahuan dan imajinasi; memiliki semangat mandiri kerjasama dan berkompetensi perlu dilatih untuk terbiasa bekerja mandiri, kerjasama dan berkompetensi; menciptakan kondisi yang menyenangkan; mengembangkan kemampuan dan pengalaman belajar; karakteristik mata pelajaran. 
Kerangka Kualifikasi Nasional Indonesia (KKNI)

Untuk menciptakan tenaga kerja yang kompeten dalam dunia kerja yang bisa bersaing diperlukan pengakuan kualifikasi sumberdaya manusia Indonesia melalui upaya peningkatan pengakuan dan penyetaraan kualifikasi baik di dalam dan di luar negeri. Melalui pengakuan kualifikasi sumber daya manusia Indonesia, kompetensi individu akan diketahui dan dapat disandingkan pada ranah pekerjaan atau bidang tugasnya. Pengakuan itu dilakukan melalui pedoman yang disebut dengan Kerangka Kualifikasi Nasional Indonesia.

Dalam Permendikbud No. 49 Tahun 2014 Bab I Pasal 1 ayat 5 dijelaskan bahwa:

"Kerangka Kualifikasi Nasional Indonesia, yang selanjutnya disingkat KKNI, adalah kerangka penjenjangan kualifikasi kompetensi yang dapat menyandingkan, menyetarakan, dan mengintegrasikan antara bidang pendidikan dan bidang pelatihan kerja serta pengalaman kerja dalam rangka pemberian pengakuan kompetensi kerja sesuai dengan struktur pekerjaan di berbagai sektor".?

KKNI merupakan sistem yang berdiri sendiri dan merupakan jembatan antara sektor pendidikan dan pelatihan untuk membentuk sumber daya manusia nasional berkualifikasi (qualified person) dan bersertifikasi (certified person) melalui skema pendidikan formal, non formal, informal, pelatihan kerja atau pengalaman kerja.

\footnotetext{
${ }^{7}$ Buku Kurikulum Pendidikan Tinggi sebagaimana disusun oleh Tim Kurikulum dan pembelajaran Direktorat Pembelajaran dan Kemahasiswaan, Direktorat Jenderal Pendidikan Tinggi Kementerian Pendidikan dan Kebudayaan; 2014
}

KKNI adalah kerangka kualifikasi yang disepakati secara nasional, disusun berdasarkan suatu ukuran pencapaian proses pendidikan sebagai basis pengakuan terhadap hasil pendidikan seseorang yang diperoleh melalui pendidikan formal, pendidikan nonformal dan pendidikan informal. Dengan adanya KKNI ini akan merubah cara melihat kompetensi seseorang, tidak lagi semata ijazah tapi dengan melihat kepada kerangka kualifikasi yang disepakati secara nasional sebagai dasar pengakuan terhadap hasil pendidikan seseorang secara luas yang akuntabel dan transparan.

\section{Kurikulum Nasional Berbasis Kompetensi Mengacu pada KKNI}

Peraturan Pemerintah No. 17 Tahun 2010 Pasal 97 menyatakan bahwa kurikulum perguruan tinggi dikembangkan dan dilaksanakan berbasis kompetensi (KBK). Pernyataan ini telah menegaskan kembali Kepmendiknas No. 232 tahun 2000 tentang Pedoman Penyusunan Kurikulum Pendidikan Tinggi dan Penilaian Hasil Belajar Mahasiswa, serta No. 045 tahun 2002 tentang Kurikulum Inti Pendidikan Tinggi.

Kurikulum yang pada awalnya mengacu pada pencapaian kompetensi menjadi mengacu pada capaian pembelajaran (learning outcomes). Pelaksanaan KKNI melalui 7 tahapan yaitu melalui penetapan Profil Kelulusan, merumuskan Learning Outcomes, Merumuskan Kompetensi Bahan Kajian, pemetaan Learning Outcomes Bahan Kajian,pengemasan Matakuliah, Penyusunan Kerangka kurikulum, Penyusunan Rencana Perkuliahan. $^{8}$

\footnotetext{
8 Kerangka Kualifikasi Nasional Indonesia-Kajian Tentang Implikasi dan Strategi Implementasi KKNI; Direktorat Jenderal Pendidikan Tinggi 2010/2011 Kementerian Nasional Pendidikan Tinggi Indonesia.
} 
Dengan adanya KKNI ini diharapkan akan mengubah cara melihat kompetensi seseorang, tidak lagi semata Ijazah tapi dengan melihat kepada kerangka kualifikasi yang disepakati secara nasional sebagai dasar pengakuan terhadap hasil pendidikan seseorang secara luas (formal, non formal, atau in formal) yang akuntanbel dan transparan. Kompetensi adalah akumulasi kemampuan seseorang dalam melaksanakan suatu deskripsi kerja secara terukur melalui asesmen yang terstruktur, mencakup aspek kemandirian dan tanggung jawab individu pada bidang kerjanya. Capaian Pembelajaran (learning outcomes) merupakan internalisasi dan akumulasi ilmu pengetahuan, ketrampilan, sikap, dan kompetensi yang dicapai melalui proses pendidikan yang terstruktur dan mencakup suatu bidang ilmu/keahlian tertentu atau melalui pengalaman kerja.

Pengembangan Kurikulum Berbasis Kompetensi (KBK) dapat diselaraskan dengan KKNI dapat dilakukan melalui tahapan sebagai berikut:

Tahap Pertama, Menyusun Capaian Pembelajaran Universitas (University Lerning Outcomes). Diturunkan dari visi dan misi universitas yang mengandung profil umum lulusan sebagai competitive dan comparative advantange dari universitas. Capaian pembelajaran universitas lebih menampilkan soft skill dibandingkan hard skill yang harus dimiliki lulusan universitas.

Tahap Kedua, Merumuskan profil lulusan program studi. Profil Lulusan adalah peran yang diharapkan dapat dilakukan oleh lulusan program studi di masyarakat/dunia kerja. Profil ini adalah outcome pendidikan yang akan dituju. Profil lulusan adalah jawaban atas pertanyaan: lulusan seperti apa yang akan dihasilkan oleh program studi setelah mereka menyelesaikan seluruh rangkaian pendidikannya (outcomes). Atau "Setelah lulus nanti, akan menjadi apa saja lulusan program studi ini?" Profil ini bisa saja merupakan profesi tertentu misal dokter, pengacara, apoteker, dan lainnya, tetapi juga bisa sebuah peran tertentu seperti manajer, pendidik, peneliti, atau juga sebuah peran yang lebih umum yang sangat dibutuhkan didalam banyak kondisi dan situasi kerja seperti komunikator, kreator, pemimpin, dan sebagainya. Rumusan profil disarankan menuliskan peran profesional dan serangkaian kompetensi (learning outcomes) yang harus dimiliki lulusan untuk menjalankan peran tersebut secara profesional, akuntabel, dan berakhlak mulia, memiliki pengetahuan, keterampilan, kemandirian, dan sikap untuk menemukan, mengembangkan, serta menerapkan ilmu, teknologi, dan seni, yang bermanfaat bagi kemanusiaan. (PP No. 19 Tahun 2005 Pasal 26 ayat 4). Profil lulusan mengacu pada capaian pembelajaran universitas, agar terbentuk kesinambungan proses untuk mencapai visi dan misi universitas. Namun kekhasan lulusan program studi menjadi bagian penting untuk menunjukkan keunggulan kompetitif (competitive advantage) dari setiap progam studi.

Tahap Ketiga, Perumusan Standar Kompetensi Lulusan. Setelah menetapkan profil lulusan program studi sebagai outcome pendidikan, maka langkah selanjutnya adalah menentukan kompetensi apa saja yang harus dimiliki oleh lulusan program studi sebagai output pembelajarannya. Untuk menetapkan kompetensi lulusan, dapat dilakukan dengan menjawab pertanyaan: "Untuk menjadi profil (.......yang ditetapkan) lulusan harus mampu melakukan apa saja? " Pertanyaan ini diulang untuk setiap profil, sehingga diperoleh daftar kompetensi lulusan dengan lengkap.

Tahap Keempat, Perumusan Capaian Pembelajaran Program Studi (Program Learning Outcomes/PLO). PLO merupakan 
jabaran lengkap profil lulusan yang berkenaan dengan kompetensi apa yang harus dimiliki oleh mahasiswa setelah lulus program studi tertentu di perguruan tinggi. Learning Outcomes (Capaian Pembelajaran) sedikitnya terdiri dari dua jenis kalimat yang menyatu, yaitu kata kerja (verb) yang menunjukkan tingkat kognitif (yang menunjukkan tingkat pengetahuan yang harus dikuasai) dan atau psikomotorik (ketrampilan yang harus ditunjukkan), dan content knowledge atau kata benda (noun) yang menunjukkan tingkatan pengetahuan, yakni fakta, konsep, prosedural dan metakognitif yang dilandasi oleh sikap (afektif) yang tepat dalam melakukan pekerjaan. Capaian pembelajaran program studi dirumuskan berdasarkan hasil tracer study (studi pelacakan) dan analisis kebutuhan dunia kerja yang terkait dengan kompetensi yang dibangun, serta jenjang kualifikasi yang diacu dari Kerangka Kualifikasi Nasional Indonesia (KKNI).

Tahap Kelima, Perumusan Capaian Pembelajaran Mata Kuliah (Course Learning Outcomes/CLO). CLO dengan jelas menggambarkan apa yang akan mahasiswa ketahui dan apa yang dapat dilakukan mahasiswa di akhir perkuliahan. Capaian pembelajaran perkuliahan berbasis kinerja (performance) dan berorientasi pada hasil. CLO merupakan gambaran yang bermakna (significant) dan terkait dengan apa yang diharapkan dapat dilakukan mahasiswa di 'dunia nyata'pembelajaran yang 'benar-benar penting dalam jangka panjang'. CLO menggambarkan apa yang dapat dilakukan mahasiswa di akhir perkuliahan-manakala mereka mengintegrasikan pembelajaran dari seluruh perkuliahan diperolehnya. Setiap CLO harus sejalan dengan satu atau lebih capaian pembelajaran program studi (PLO).
Tahap Keenam, Menemukan dan mengenali Konsep Kunci dan Kata Kunci pada Capaian Pembelajaran Mata Kuliah. Pernyataan konsep kunci (key concept) tidak dimaksudkan hanya untuk concept knowledge pada ranah pengetahuan Bloom, tetapi lebih ditekankan pada content knowledge dari setiap Capaian Pembelajaran Mata Kuliah. Konsep-konsep kunci sesungguhnya merupakan daftar dari konsep inti pada perumusan bidang kajian yang dimiliki program studi. Konsep-konsep inti ini pula yang dapat dijadikan patokan dalam menghitung beban kerja mahasiswa (student work load) yang menjadi dasar perhitungan jumlah kredit untuk setiap mata kuliah. Karena dalam setiap konsep kunci yang di dalamnya terdapat kata-kata kunci (key word) dapat diduga waktu yang dibutuhkan untuk mencapai penguasaan konsep tersebut (time expectation).

Pertanyaan yang dapat membantu menemu dan mengenali konsep kunci adalah konsep-konsep penting apa (essential concept) yang paling sedikit yang dikuasai mahasiswa untuk mencapai kompetensi yang diharapkan?

Tahap Ketujuh, Pengembangan RPKPS (Rencana Program dan Kegiatan Pembelajaran Semester). Mengadaptasi pendapat Clark dan Lampert (1986) menyatakan bahwa perencanaan pembelajaran adalah determinan utama dari apa yang diajarkan. Kurikulum yang dipublikasikan, ditransformasikan, dan diadaptasikan dalam proses perencanaan dengan penambahan, penghapusan, interpretasi, dan keputusan dosen tentang kecepatan, urut-urutan, dan penekanan (pengajarannya). Dalam perencanaan pembelajaran termasuk di dalamnya mengalokasikan waktu pembelajaran untuk individu-individu dan kelompok-kelompok mahasiswa; menyusun kelompok-kelompok 
mahasiswa; mengorganisasikan jadwal harian, mingguan, dan triwulanan; dan mengompensasi waktu untuk interupsi di luar kelas dan berkomunikasi dengan dosen pengganti.

Kurikulum nasional berbasis kompetensi harus selaras dengan KKNI supaya ada dampak dalam kurikulum dan pengelolaan dalam setiap penyusunan programnya. Kurikulum yang pada awalnya mengacu pada pencapaian kompetensi menjadi mengacu pada capaian pembelajaran (learning outcomes) untuk setiap lulusan perguruan tinggi.

\section{KESIMPULAN}

Indonesia ditahun ini akan menghadapi Masyarakat Ekonomi ASEAN (MEA), dimana arus globalisasi dan perdagangan bebas tidak terelakkan lagi. Arus globalisasi dan perdagangan bebas tidak bisa mencegahnya masuknya: arus barang dan jasa; arus investasi dan arus sumber daya manusia yang kompeten. Jika bangsa Indonesia tidak menyiapkan sumber daya manusia yang kompeten, bisa jadi akan masuk sumber daya manusia dari negara lain yang berdaya saing tinggi dibidang jasa dan industri. Untuk itu bangsa Indonesia harus menyiapkan lulusannya terutama lulusan dari perguruan tinggi yang kompeten dalam bidangnya, mempunyai daya saing, menunjukkan sikap dan minat terhadap keilmuannya serta bertanggungjawab dan mempunyai kreatifitas terhadap keilmuannya. Karena itulah diperlukan pengakuan kualifikasi sumberdaya manusia Indonesia melalui upaya peningkatan pengakuan dan penyetaraan kualifikasi baik di dalam dan di luar negeri. Melalui pengakuan kualifikasi sumber daya manusia Indonesia, kompetensi individu akan diketahui dan dapat disandingkan pada ranah pekerjaan atau bidang tugasnya. Pengakuan itu dilakukan melalui pedoman yang disebut dengan Kerangka Kualifikasi Nasional Indonesia. Kerangka Kualifikasi Nasional Indonesia atau selanjutnya disebut KKNI adalah kerangka penjenjangan kualifikasi kompetensi yang dapat menyandingkan, menyetarakan, dan mengintegrasikan antara bidang pendidikan dan bidang pelatihan kerja serta pengalaman kerja dalam rangka pemberian pengakuan kompetensi kerja sesuai dengan struktur pekerjaan di berbagai sektor. KKNI dituangkan dalam Peraturan Presiden Nomor 08 Tahun 2012 serta merupakan pelaksanaan ketentuan Pasal 5 ayat (3) Peraturan Pemerintah Nomor 31 Tahun 2006 tentang Sistem Pelatihan Kerja Nasional (Sislatkernas). KKNI merupakan sistem yang berdiri sendiri dan merupakan jembatan antara sektor pendidikan dan pelatihan untuk membentuk sumber daya manusia nasional berkualifikasi (qualified person) dan bersertifikasi (certified person) melalui skema pendidikan formal, non formal, informal, pelatihan kerja atau pengalaman kerja.

Kurikulum perguruan tinggi yang sudah merupakan kurikulum nasional berbasis kompetensi yang diselaraskan dengan kerangka kualifikasi nasional Indonesia diharapkan manusia Indonesia memenuhi kualifikasi yang dibutuhkan dalam dunia kerja. Lulusan perguruan tinggi tidak hanya memperhatikan lulusan yang mempunyai kemampuan secara hard skill tapi secara soft skillnya menjadi lulusan yang berkemampuan tidak hanya secara keilmuan tapi lulusan betul-betul mengerti tujuan akhir dari proses pendidikannya sehingga menjadi lulusan yang bertanggung jawab pada profesinya.

Penyusunan kurikulum perguruan tinggi yang berdasarkan kurikulum nasional berbasis kompetensi dengan mengacu pada kerangka kualifikasi nasional Indonesia 
memang tidak bisa menjawab semua persoalan dalam bidang pendidikan khususnya perguruan tinggi. Tapi penyusunan kurikulum berbasis kompetensi yang mengacu pada KKNI perlu diterapkan pada setiap perguruan tinggi yang ada di Indonesia supaya tujuan bangsa Indonesia untuk mengahsilkan lulusan yang kompeten dalam bidangnya serta punya daya saing serta bertanggung jawab akan segera terwujud. Pergerakan yang dilakukan secara bersamasama oleh smua perguruan tinggi yang ada di Indonesia akan mempercepat proses perubahan manusia Indonesia menjadi sumber daya manusia yang berkualitas baik.

Bagi Pendidikan Tinggi Hukum adanya kurikulum nasional berbasis kompetensi dengan mengacu pada kerangka kualifikasi nasional Indonesia diharapkan lulusannya bisa terlibat dan mempunyai daya saing bagi kualitas lulusannya ketika menghadapi Masyarakat Ekonomi ASEAN (MEA). Lulusan tersebut tidak saja bisa menjadi tenaga kerja yang menempati lapangan pekerjaan tertentu tapi lebih pada lulusan yang mampu menyelesaikan permasalahan hukum dengan disertai bakat dan minat pada keilmuannya. Kemampuan menyelesaikan setiap permasalahan hukum secara bertanggung jawab diharapkan dapat menjadi nilai plus bagi lulusan pendidikan tinggi hukum ketika harus bersaing menghadapi globalisasi dan perdagangan bebas di masamasa kedepannya.

\section{Daftar Pustaka:}

\section{Buku}

E. Mulyasa Prof. Dr.H. MPd; Implementasi Kurikulum $2004 \quad$ Panduan Pembelajaran KBK; Remaja Rosda Karya; 2005
Sudjatmiko, dkk; Kurikulum Berbasis Kompetensi Dalam Menunjang Kecakapan Hidup Siswa; (Jakarta: Depdiknas 2003);

Tim Kurikulum dan Pembelajaran Direktorat Pembelajaran dan Kemahasiswaan, Direktorat Jenderal Pendidikan Tinggi Kementerian Pendidikan dan Kebudayaan; Buku Kurikulum Pendidikan Tinggi; 2014

Direktorat Jenderal Pendidikan Tinggi 2010/2011 Kementerian Nasional Pendidikan Tinggi Indonesia; Kerangka Kualifikasi Nasional Indonesia-Kajian Tentang Implikasi dan Strategi Implementasi KKNI

\section{Website}

www.dikti.go.id 